\title{
Comparative Mineral Mapping in the Colorado Mineral Belt using AVIRIS and ASTER Remote Sensing Data
}

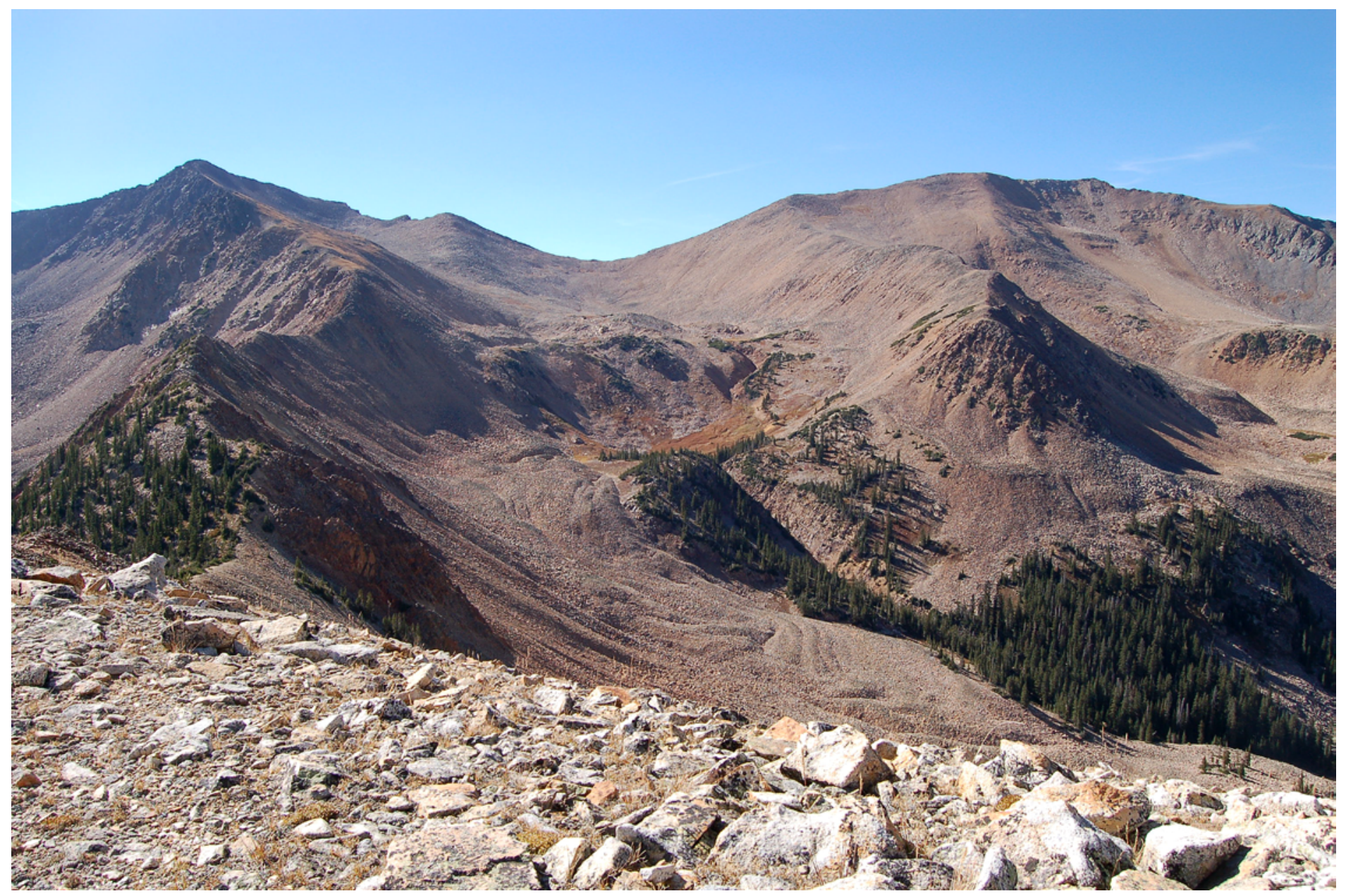

Scientific Investigations Map 3256 
Photo Caption. Bleached, argillized rocks of the Mount Cumulus stock at the summit of Red Mountain with the high ridgeline of the Never Summer Mountains in the background to the west. 


\section{Comparative Mineral Mapping in the Colorado Mineral Belt using AVIRIS and ASTER Remote Sensing Data}

By Barnaby W. Rockwell

Pamphlet to accompany

Scientific Investigations Map 3256 


\title{
U.S. Department of the Interior SALLY JEWELL, Secretary
}

\section{U.S. Geological Survey Suzette M. Kimball, Acting Director}

\author{
U.S. Geological Survey, Reston, Virginia: 2013
}

For more information on the USGS - the Federal source for science about the Earth, its natural and living resources, natural hazards, and the environment, visit http://www.usgs.gov or call 1-888-ASK-USGS.

For an overview of USGS information products, including maps, imagery, and publications, visit http://www.usgs.gov/pubprod

To order this and other USGS information products, visit http://store.usgs.gov

Any use of trade, firm, or product names is for descriptive purposes only and does not imply endorsement by the U.S. Government.

Although this information product, for the most part, is in the public domain, it also may contain copyrighted materials as noted in the text. Permission to reproduce copyrighted items must be secured from the copyright owner.

Suggested citation:

Rockwell, B.W., 2013, Comparative mineral mapping in the Colorado Mineral Belt using AVIRIS and ASTER remote sensing data: U.S. Geological Survey Scientific Investigations Map 3256, 8 p. pamphlet, 1 map sheet, scale 1:150,000, http://pubs.usgs.gov/sim/3256/. 


\section{Contents}

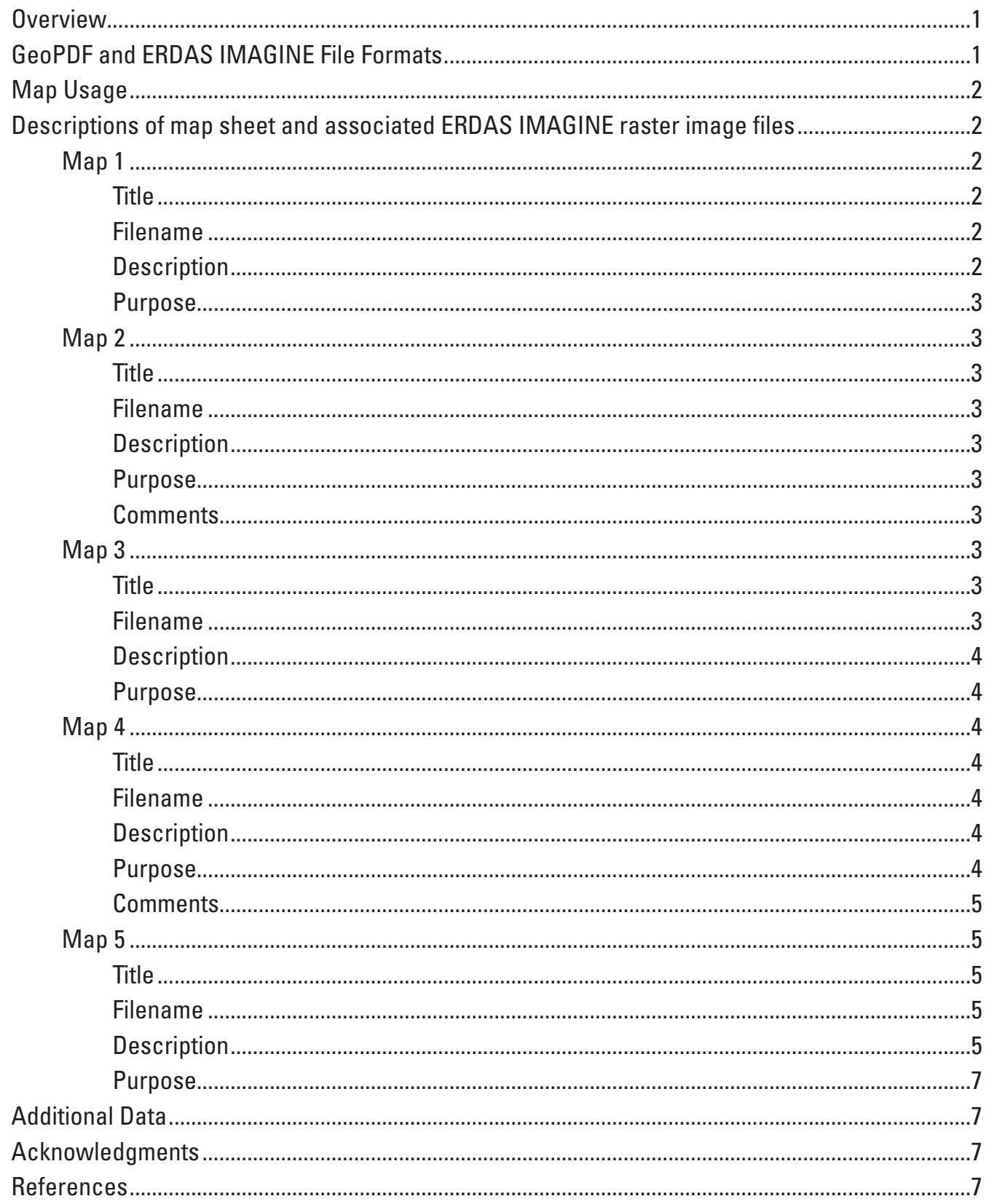




\section{Tables}

1. Generalized guide for preliminary interpretation of mineral maps ....................................2

2. Boolean logic used to combine results of a) separate iron mineral, vegetation, and water analysis (mainly VNIR absorptions, see Map 3) and b) clay, sulfate, mica, carbonate, and hydrous silica mineral analysis (mainly SWIR absorptions, see Map 4) into a single map of hydrothermal alteration type (Map 5).

\section{Map}

Map of modeled hydrothermal alteration type derived from ASTER data: Comparative mineral mapping in the Colorado Mineral Belt using AVIRIS and ASTER remote sensing data link

\section{Conversion Factors}

SI to Inch/Pound

\begin{tabular}{lcl}
\hline \multicolumn{1}{c}{ Multiply } & By & \multicolumn{1}{c}{ To obtain } \\
\hline & Length & \\
\hline kilometer $(\mathrm{km})$ & 0.6214 & mile $(\mathrm{mi})$ \\
meter $(\mathrm{m})$ & 3.281 & foot $(\mathrm{ft})$ \\
micrometer $(\mu \mathrm{m})$ & 0.001 & millimeter $(\mathrm{mm})$ \\
\hline
\end{tabular}




\title{
Comparative Mineral Mapping in the Colorado Mineral Belt using AVIRIS and ASTER Remote Sensing Data
}

\author{
By Barnaby W. Rockwell
}

\section{Overview}

This report presents results of interpretation of spectral remote sensing data covering the eastern Colorado Mineral Belt in central Colorado, U.S.A., acquired by the Airborne Visible/Infrared Imaging Spectrometer (AVIRIS) and Advanced Spaceborne Thermal Emission and Reflection Radiometer (ASTER) sensors. This study was part of a multidisciplinary mapping and data integration project that focused on long-term resource planning by land-managing entities in Colorado. The project supported studies related to understanding the availability of mineral and energy resources, the geochemical and environmental effects of mining and undisturbed, hydrothermally altered rocks, the geoenvironmental effects of wildfires, geologic controls of groundwater availability and quality, and geologic hazards (Klein, 2007).

The results relating to mineral occurrence and distribution were an important source of data for studies documenting the effects of mining and un-mined, altered rocks on aquatic ecosystems at the watershed level (Schmidt and others, 2012). The results were also part of a database that integrated geologic data from a variety of sources to identify watersheds in which there are hydrothermally altered rocks, mine waste, and (or) or tailings containing mineralogy associated with sulfide mineral oxidation (Church and others, 2012). These studies demonstrated a high correlation between metal concentrations in streams and the presence of hydrothermal alteration and (or) pyritic mine waste as determined by analysis of the remote sensing data presented herein. The mineral mapping results were also used to delineate permissive areas for various mineral deposit types.

\section{GeoPDF and ERDAS IMAGINE File Formats}

Digital mineral and vegetation mapping results are presented in GeoPDF and ERDAS IMAGINE format (.img) (Intergraph, 2012). Georeferencing information is included in both file types. The TerraGo® Toolbar (http:// www.terragotech.com/products/field-data-collection/ terrago-toolbar), a no-cost extension for Adobe Acrobat Reader, is required for viewing geographic coordinates in the GeoPDF-format map sheet. With or without the toolbar, multiple, geographically referenced map layers within the GeoPDF file can be turned on and off to generate custom maps for viewing and printing using the Layers tool on the left side of the Acrobat Reader window. The GeoPDF file contains five layers of AVIRIS- and ASTER-derived mineral and vegetation maps (identified as Maps 1-5 in the Layers list), color composite images of the three AVIRIS flight lines, and a layer showing areas that were excluded from the ASTER data analysis because of data errors, snow, clouds, and cloud shadow. Map 5, showing modeled alteration type and key mineral groups derived from Boolean combination of Maps 3 and 4, is displayed in the GeoPDF by default when the file is opened. Explanations of the colors assigned to material detections and modeled alteration classes for the five maps are provided at the bottom of the map sheet. Subsidiary map layers showing the 1:500,000-scale geologic map of Colorado (Tweto, 1979; Green, 1992), administrative boundaries, roads, surface hydrology, and landmarks (for example, National Parks) are also included. These layers, derived from ArcGIS Online (Esri, 2012), are included to make the maps more useful by displaying geographic features of interest, but may not conform to U.S. Geological Survey (USGS) map standards, and in some cases may interfere with viewing the AVIRIS- and ASTER-derived mineral and vegetation maps. Several of these geographic map layers are scale-dependent; for example, more detailed, lower-order watercourses in the "Water" layer appear when viewed at larger scales.

The ERDAS-format files are suitable for integration with other geospatial data in Geographic Information Systems (GIS). The files have been attributed according to identified or modeled material (mineral assemblage, vegetation class, or alteration type), which enables the color-coded pixels to be interactively queried with the attribute identification tools of GIS and image processing software packages (for example, the Identify Tool of ArcMap and the Inquire Cursor Tool of ERDAS IMAGINE). For the attribute information to appear in the ArcMap Table of Contents, open the ERDAS file in ArcMap and symbolize using Unique Values for the "Materialid" or "Alteration" value fields. Metadata compliant with Federal Geographic Data Committee (FGDC) standards have been included for the ERDAS-format files, and contain important information regarding geographic coordinate systems, attributes describing identified materials, and bibliographic cross-references. 


\section{Map Usage}

The image map was designed primarily for the regional mapping and characterization of exposed surface mineralogy, including that related to hydrothermal alteration and supergene weathering of pyritic rocks (Rockwell, 2012). As hydrolytic alteration commonly occurs along faults and fractures that serve as conduits for potentially metal-bearing fluids, the presence and type of alteration can provide important information for mineral resource investigations. Prospective areas for epithermal and porphyry-type mineralization in which alteration is identified are, in general, more likely to host near-surface deposits.

Pyrite, a common gangue mineral important for geoenvironmental studies, is associated with hydrothermal alteration and many types of ore deposits. Weathering of pyrite produces sulfuric acid that can leach and transport potentially toxic metals into the surface water and groundwater systems. Knowledge of pyrite occurrence and the extent and type of alteration is vital in developing predictive models of downstream surface water geochemistry in both mined and unmined catchments, and to evaluate pre- and post-mining effects of altered areas on local hydrology. Clay and ferric iron minerals including jarosite, copiapite, melanterite, and goethite are also produced during the supergene weathering process. Such iron minerals can be identified and differentiated using spectroscopic remote sensing data such as that acquired by the AVIRIS sensor, but the low spectral resolution of ASTER data permit only the detection of undifferentiated ferric iron (Rockwell, 2009). Anomalous concentrations of ferric iron minerals in volcanic rocks and mine waste can be used as a proxy for pyrite occurrence. Mine waste and tailings in which no minerals were detected are less likely to represent exposed, nonpoint sources of acidic solutions, or are too small in size to be mapped using the remote sensing data. The maps can also be used to evaluate mineral exposure at mine sites that have undergone remediation prior to the acquisition of the image data.

The mineral maps can be best interpreted in conjunction with geologic maps in a GIS environment. The mineral mapping results can be compared to the regional geologic map included in the GeoPDF-format map sheet to determine the lithologic or alluvial unit(s) in which an identified mineral occurrence is located. An explanation for the lithologic units on this geologic map is available at http://geology.about.com/ library/bl/maps/n_statemap_COexp.htm. The origin of an identified mineral occurrence can begin to be understood by recognizing the host rock lithology or material type (table 1). Most occurrences of hydrothermal alteration contain phyllosilicate and (or) sulfate minerals with or without iron, but a vast majority of identified mineral occurrences shown on the maps are unrelated to alteration. Within volcanic rocks and mine waste, the presence of hydrolytic alteration and (or) supergene weathering of pyrite can be inferred if both ferric iron and phyllosilicate and (or) sulfate minerals are present, especially in the same pixel. Acid-neutralizing propylitic alteration can be inferred if calcite, chlorite, epidote, and ferrous ironbearing minerals are detected (Yager and others, 2008). The maps may aid in the refinement of geologic maps by delineating lithologic and alluvial units in which minerals identifiable using spectral remote sensing exist in abundance.

Table 1. Generalized guide for preliminary interpretation of mineral maps.

\begin{tabular}{ll}
\hline $\begin{array}{c}\text { Host rock or } \\
\text { material type }\end{array}$ & \multicolumn{1}{c}{$\begin{array}{c}\text { Highest-probability origin of } \\
\text { mineral occurrence }\end{array}$} \\
\hline volcanic & fresh and weathered hydrothermal alteration \\
plutonic & lithology (commonly mica) or alteration \\
sedimentary & $\begin{array}{c}\text { lithology (commonly mica }+/ \text { - clays }+/- \\
\text { carbonates), diagenesis }\end{array}$ \\
metamorphic & $\begin{array}{l}\text { lithology, weathering, metamorphic grade } \\
\text { and type }\end{array}$ \\
alluvium & erosion and weathering \\
mine waste and & alteration and (or) supergene weathering of \\
tailings & pyritic rocks \\
\hline
\end{tabular}

\section{Descriptions of map sheet and associated ERDAS IMAGINE raster image files}

The map sheet contains various data layers that are referred to as Maps 1 through 5 in the GeoPDF layer list. These maps are also provided in GIS-ready ERDAS IMAGINE format with associated metadata, and are described below.

\section{Map 1:}

Title:

AVIRIS-DERIVED MAP OF IRON-BEARING MINERAL ASSEMBLAGES AND WATER

\section{Filename:}

aviris00_mosaic_1um_arcspline_utm_rgbclus_zfix_rle.img

\section{Description:}

This image shows the spatial occurrence of iron-bearing minerals and water identified using AVIRIS data based on spectral similarity between image spectra and laboratory reference spectra of well-characterized materials and material mixtures. These materials have diagnostic spectral absorption features primarily in the visible and near-infrared (VNIR) regions of the electromagnetic spectrum. 
The image is a mosaic of three flight lines of high-altitude AVIRIS data acquired from $20 \mathrm{~km}$ altitude on June 21, 2000. These data have a ground instantaneous field-of-view (GIFOV) of approximately $17 \mathrm{~m} /$ pixel, although this value will increase slightly with altitude of the ground surface. The data were calibrated to reflectance using techniques described by Rockwell and others (2002a; 2002b) and field spectral data of a parking lot at the Copper Mountain ski area located $10 \mathrm{~km}$ west of Breckenridge. The data were analyzed using a modified expert system (Rockwell, 2002) for comparing the spectral shapes of image spectra to laboratory reference spectra using least-squares curve fitting (Rockwell and others, 2005, 2006; Rockwell, 2009).

The AVIRIS flight lines were georeferenced to orthoimagery using control points and a cubic spline algorithm before mosaicking. The image file uses lossless run-length encoding compression to reduce file size.

\section{Purpose:}

The high spectral resolution of AVIRIS data permits the identification of specific species of iron-bearing minerals that is impossible with ASTER data (Rockwell, 2004; 2009). Identified areas of jarosite are most likely to contain oxidizing pyrite and (or) other sulfide minerals that generate sulfuric acid during weathering. Identified goethite may indicate rocks with less abundant or fully oxidized pyrite. The image has been attributed by pixel value with material identification data that can be queried in most image processing and GIS software packages. This attribute information, including pixel values and assigned colors, is described in the accompanying metadata.

\section{Map 2:}

Title:

AVIRIS-DERIVED PHYLLOSILICATE, SULFATE, CARBONATE, SOROSILICATE, AND NESOSILICATE MINERALS

\section{Filename:}

aviris00_mosaic_2um_arcspline_utm_rgbclus_zfix_rle.img

\section{Description:}

This image shows clay, sulfate, mica, carbonate, $\mathrm{Mg}-\mathrm{OH}$, and nesosilicate (topaz) minerals identified using AVIRIS data based on spectral similarity between image spectra and laboratory reference spectra of well-characterized materials and material mixtures. These minerals have diagnostic spectral absorption features primarily in the shortwave infrared (SWIR) region of the electromagnetic spectrum. See description of Map 1 for information on AVIRIS data processing and analysis.

\section{Purpose:}

The purpose of the image is to display the spatial distributions of pure and mixed clay, sulfate, mica, carbonate, $\mathrm{Mg}-\mathrm{OH}$, and nesosilicate (topaz) minerals. Mineral assemblages containing kaolinite, pyrophyllite, topaz, and jarosite are most likely to be related to hydrothermal alteration and (or) supergene weathering of pyritic rocks. The image has been attributed by pixel value with material identification data that can be queried in most image processing and GIS software packages. This attribute information, including pixel values and assigned colors, is described in the accompanying metadata.

\section{Comments:}

A small occurrence of topaz was mapped in the center of the Climax molybdenum mine north of Leadville, and is shown on the map in a dark red color. More extensive exposures of quartz-sericite-pyrite (QSP) alteration were identified to the north of the topaz exposure, and are expressed on the map as the "jarosite + sericite +/- gypsum" mineral mixture shown in cyan. Topaz occurs as an accessory mineral in the ore assemblages of many Climax-type porphyry molybdenum deposits (Ludington and Plumlee, 2009), and in fluorine-rich rhyolites and granites (Haapala, 1997).

A northeast-trending fracture zone containing pyrophyllite, kaolinite, sericite, and jarosite (after pyrite) was identified on a high ridge forming the southern end of Grizzly Gulch, 8.7 $\mathrm{km}$ south of Saint Elmo and $1.6 \mathrm{~km}$ east-northeast of Pomeroy Mountain in the Sawatch Range. The fracture zone is intensely iron stained and occurs within intermediate composition rocks of the Mount Princeton pluton in an area permissive for porphyry molybdenum deposits. The ASTER data analysis identified ferric iron of the highest abundance (Map 3) and low-abundance Al sericite (Map 4) in this area. The argillized fracture zone is too narrow to be identified using ASTER SWIR data having a 30-m GIFOV (ground pixel size).

\section{Map 3:}

Title:

ASTER-DERIVED IRON-BEARING MINERAL ASSEMBLAGES, VEGETATION, AND WATER

\section{Filename:}

cmb_fe-veg_bootcal_8scene_mosaic_02top_3-10_geofix rgbclus_filt3focmaj_rle.img 


\section{Description:}

This image shows iron-bearing minerals, vegetation groups, and water identified using ASTER data based on spectral similarity between image spectra and laboratory reference spectra of well-characterized materials and material mixtures. These materials have diagnostic spectral absorption features primarily in the visible and near-infrared (VNIR) regions of the electromagnetic spectrum.

The image is a mosaic of eight ASTER scenes from two overpasses, or paths, of the Terra satellite. The four scenes from the western path were acquired on September 2, 2002, and the four scenes from the eastern path were acquired on September 14, 2003. Reflectance-calibrated AVIRIS data over Georgetown to the east of the study area were used as a reference base to calibrate the ASTER data to reflectance using a "bootstrap" method described by Rockwell and others (1999). The ASTER scenes were analyzed using methodologies described by Rockwell (2009). An example of a seamless, two-scene mosaic of ASTER-derived mineral mapping results produced by the same analysis methodology is provided by Rockwell (2010). A different contrast stretch in which green vegetation appears in hues of slightly brighter green was applied to the northeasternmost scene to highlight the geographic coverage of a single ASTER scene.

The mosaic has been georeferenced to orthoimagery using control points and a cubic spline algorithm. The scenes from the western path were acquired with an $\sim 8.5^{\circ}$ off-nadir pointing angle, and thus had positional errors of up to $400 \mathrm{~m}$. The image file uses lossless run-length encoding compression to reduce file size. The results were simplified using a $3 \times 3$ focal majority filter to reduce the occurrence of non-contiguous, single-pixel material identifications.

\section{Purpose:}

The purpose of the image is to display the spatial distributions of iron-bearing minerals, vegetation groups differentiated by variations in chlorophyll content and dryness, and volatiles (water and snow). Most ferric iron associated with oxidation of hydrothermal pyrite in unmined rocks or mine waste is shown in shades of red. Minor ferric iron associated with lithology and (or) weathering of iron-bearing minerals is shown in shades of orange. Brighter shades of color indicate increased least-squares fit $\times$ depth of diagnostic absorption features, which correlates with mineral group abundance given a constant grain size. Identified green, dry and green, and dry vegetation can be used to evaluate vegetative cover at the times of ASTER data acquisition (Rockwell, 2009). The image has been attributed by pixel value with material identification data that can be queried in most image processing and GIS software packages. This attribute information, including pixel values and assigned colors, is described in the accompanying metadata.

\section{Map 4:}

Title:

ASTER-DERIVED MAP OF PHYLLOSILICATE, SULFATE, CARBONATE, SOROSILICATE, AND SILICA MINERALS

\section{Filename:}

aster_cmb_swir_mosaic_2-08_3199gf_overlapfix2.img

\section{Description:}

This image shows clay, sulfate, mica, carbonate, $\mathrm{Mg}-\mathrm{OH}$, and hydrous quartz minerals identified using ASTER data based on spectral similarity between image spectra and laboratory reference spectra of well-characterized materials and material mixtures. These minerals have diagnostic spectral absorption features primarily in the shortwave infrared (SWIR) region of the electromagnetic spectrum. Identification of jarosite was based on analysis of diagnostic ferric iron and Fe-OH absorptions in the VNIR and SWIR, respectively (Rockwell, 2009). ASTER data processing and analysis procedures are identical to those used to generate the data shown in Map 3 other than the majority filtering, which was not applied.

Mineral identifications on north-facing alpine slopes can be erroneous because of poor solar illumination and SWIR detector instability over dark (low albedo) surfaces. North-facing slopes, many of which were in shadow at the time (approximately $10 \mathrm{a}$.m.) of data acquisition, were isolated using an aspect image derived from a digital elevation model (DEM) of 30-m resolution. A mask was made of surfaces with azimuths between $270^{\circ}$ and $73^{\circ}$ and elevations greater than $3,199 \mathrm{~m}$. Mineral identifications in Maps 4 and 5 that occurred within the mask area were attributed to indicate their potentially erroneous nature. For example, high-abundance sericite occurring on these poorly-illuminated surfaces was renamed "primarily false detections of high-abundance sericite on shadowed, north-facing slopes" on Map 4.

\section{Purpose:}

The purpose of the image is to display the spatial distributions of clay, sulfate, mica, carbonate, $\mathrm{Mg}-\mathrm{OH}$, and hydrous quartz minerals. The image has been attributed by pixel value with material identification data that can be queried in most image processing and GIS software packages. This attribute information, including pixel values and assigned colors, is described in the accompanying metadata. 


\section{Comments:}

Kaolinite was verified on the upper, south face of Radial Mountain west of the Never Summer Mountains $(18 \mathrm{~km}$ northnorthwest of the town of Grand Lake) within intermediatecomposition rocks of the Radial Mountain stock; on the summit of Red Mountain in the Never Summer Mountains within felsic rocks of the Mount Cumulus stock; on the southwestern flank of Jenkins Mountain in the Sawatch Range above the Pieplant mine in Taylor Park, within felsic, leucocratic rocks of the Twin Lakes stock; and within poorly-consolidated alluvial and colluvial deposits of the Dry Union Formation (Miocene to Pliocene) $2 \mathrm{~km}$ west of the town of Granite in the Arkansas River Valley.

Sericite (fine-grained muscovite) and minor chlorite were identified using laboratory spectroscopy in cobbles of porphyritic intrusive rock within Holocene to Pleistocene alluvium $8.7 \mathrm{~km}$ north-northwest of Granite in the Arkansas River Valley. The ASTER SWIR data of this area are characterized by absorptions at 2.20 and 2.34 micrometers (caused by sericite and calcite, respectively), and the area was identified in Map 4 as "sericite (or smectite) + calcite (and/or chlorite, epidote)."

No advanced argillic alteration (alunite, pyrophyllite) identified using the ASTER data has been verified in the field or laboratory. Pixels identified as alunite and (or) pyrophyllite with the ASTER SWIR data are most likely areal mixtures of well-crystallized kaolinite and dry vegetation. Such mixtures can result in a spectral response similar to advanced argillic alteration minerals (Rockwell, 2009; John and others, 2010), although the presence of these minerals cannot be ruled out without field verification.

Tailings at the mill located $26 \mathrm{~km}$ north of Silverthorne associated with the Henderson molybdenum mine have deep spectral absorption at 2.17 micrometers consistent with alunite and pyrophyllite, but it is highly unlikely that these minerals exist there. These tailings have not been field checked. Lowabundance ferric iron minerals were also identified in the tailings deposit.

Pixels having a similar spectral response were identified at the western end of the Twin Lakes southwest of Leadville, and are shown in red on Maps 4 and 5. The water level in the lakes was low at the time of ASTER data acquisition, and the western end of the western lake was exposed. This area was covered by water in 2011. Ferric iron minerals (Map 3) identified there may be related to oxidation of pyrite derived from intense phyllic alteration in the Grizzly Peak caldera 12-20 $\mathrm{km}$ to the west-southwest of the Twin Lakes. Acid rock drainage derived from this alteration is known to have affected the geochemistry of South Fork Lake Creek that drains eastward into the Twin Lakes (Neubert and others, 2011).

\section{Map 5:}

Title:

ASTER-DERIVED ALTERATION TYPE AND KEY
MINERAL ASSEMBLAGES GROUPED BY RELATIVE
NET ACID PRODUCTION AND ACID NEUTRALIZING
CAPACITY

Filename:

aster_cmb_mosaic_alteration-merge_rle.img

\section{Description:}

This image shows the results of a methodology designed to simplify and combine the mineral occurrence information contained in Maps 3 and 4 into a single map showing the spatial distribution of hydrothermal alteration types and (or) carbonate rocks. This methodology is similar to that described by Rockwell (2012, sheet 4). Although carbonate rocks can be isolated from propylitic alteration through integration with a digital lithologic map, carbonate rocks are included because of their strong acid neutralizing capacity and importance to geoenvironmental modeling.

In the map explanation, alteration types and key mineral assemblages have been grouped by relative net acid production (NAP) and acid-neutralizing capacity (ANC). These groups are ordered by decreasing NAP from upper left to lower right.

Hydrothermal alteration types are defined based on the presence of mineral assemblages, and diagnostic minerals for such definitions are identified from both the VNIR (Map 3) and SWIR (Map 4) spectral regions that are analyzed separately. Therefore, a suite of Boolean equations was developed that combines the mineralogic information from the two spectral regions (table 2) into a single map. 
Table 2. Boolean logic used to combine results of a) separate iron mineral, vegetation, and water analysis (mainly VNIR absorptions, see Map 3) and b) clay, sulfate, mica, carbonate, and hydrous silica mineral analysis (mainly SWIR absorptions, see Map 4) into a single map of hydrothermal alteration type (Map 5). Logic from analyses a) and b) are considered separately and are linked by an inferred AND operator. For example, a pixel will be modeled as Phyllic (QSP) alteration if minor or major ferric iron were identified AND either kaolinite + smectite, kaolinite + sericite, or high-abundance sericite. Logic in blank cells was ignored.

\begin{tabular}{|c|c|c|c|c|c|c|c|c|c|c|c|c|c|c|c|c|}
\hline & \multicolumn{2}{|c|}{$\begin{array}{l}\text { a) Iron mineral, } \\
\text { vegetation, and } \\
\text { water analysis }\end{array}$} & \multicolumn{14}{|c|}{ b) VNIR-SWIR mineral analysis } \\
\hline & $\begin{array}{l}\text { major } \\
\text { ferric } \\
\text { iron }\end{array}$ & $\begin{array}{l}\text { minor } \\
\text { ferric } \\
\text { iron }\end{array}$ & $\begin{array}{l}\text { kaolinite } \\
\text { + smectite }\end{array}$ & alunite & $\begin{array}{l}\text { alunite + } \\
\text { kaolinite }\end{array}$ & $\begin{array}{l}\text { kandite } \\
\text { clay }\end{array}$ & $\begin{array}{c}\text { kaolinite + } \\
\text { sericite }\end{array}$ & $\begin{array}{c}\text { Al } \\
\text { sericite }\end{array}$ & $\begin{array}{c}\mathrm{Fe} / \mathrm{Mg} \\
\text { sericite, or } \\
\text { muscovite } \\
\text { + chlorite }\end{array}$ & jarosite & smectite & calcite & dolomite & $\begin{array}{c}\text { epidote, } \\
\text { or } \\
\text { calcite + } \\
\text { dolomite }\end{array}$ & chlorite & $\begin{array}{l}\text { calcite + } \\
\text { sericite }\end{array}$ \\
\hline Advanced argillic & & & & OR & OR & & & & & & & & & & & \\
\hline Argillic (or clay-bearing rocks) & NOT & NOT & OR & & & OR & OR & & & & OR & & & & & \\
\hline Argillic + ferric iron & OR & OR & & & & OR & & & & & OR & & & & & \\
\hline Phyllic (QSP) & OR & OR & OR & & & & OR & $\begin{array}{l}\text { OR (high } \\
\text { abundance)* }\end{array}$ & & & & & & & & \\
\hline Pyritic (jarosite) & & & & & & & & & & $\mathrm{X}$ & & & & & & \\
\hline $\begin{array}{l}\text { Propylitic or carbonate rocks +/- } \\
\text { sericite or smectite }\end{array}$ & NOT & NOT & & & & & & & & & & OR & OR & OR & OR & OR \\
\hline $\begin{array}{l}\text { Propylitic or carbonate rocks +/- } \\
\text { sericite or smectite }+ \text { ferric iron }\end{array}$ & OR & OR & & & & & & & & & & OR & OR & OR & OR & OR \\
\hline Regional propylitic to weak QSP & OR & OR & & & & & & $\begin{array}{l}\text { X (low } \\
\quad \text { abundance) }\end{array}$ & & & & & & & & \\
\hline $\begin{array}{l}\text { Possible regional propylitic } \\
\text { (sericite + chlorite) }\end{array}$ & & & & & & & & & $\mathrm{X}$ & & & & & & & \\
\hline Sericitic (mainly lithologic) & NOT & NOT & & & & & & $\begin{array}{l}\mathrm{X} \text { (high } \\
\text { abundance) }\end{array}$ & & & & & & & & \\
\hline
\end{tabular}

$$
\text { AND }
$$

*Modeled phyllic alteration on north-facing alpine slopes where SWIR mineral detections may be erroneous has been attributed as "potential phyllic (QSP) on north-facing slopes." 
Where they co-occur with ferric iron minerals from Map 3, potentially false occurrences of high-abundance $\mathrm{Al}$ sericite on north-facing alpine slopes (see Map 4 description above) are labeled as "potential phyllic (QSP) on north-facing slopes" on Map 5. See description of Map 4 for procedures used to isolate north-facing, high-elevation slopes.

\section{Purpose:}

The image shows the occurrence of alteration types, key mineral groups, and dense green vegetation. The image provides an easily interpretable tool for geologists, watershed modelers, and land managers engaged in geoenvironmental watershed modeling and mineral resource assessment at regional to national scales. The image has been attributed by pixel value with material identification data that can be queried in most image processing and GIS software packages. This attribute information, including pixel values and assigned colors, is described in the accompanying metadata.

\section{Additional Data}

A raster image that indicates areas excluded from the ASTER data analysis because of corrupted SWIR data (detector "scratch," Rockwell, 2009; 2012), snow at high elevations (eastern ASTER path only), clouds, and cloud shadow is included in the GeoPDF map sheet and in ERDAS IMAGINE format. The image is named "aster_mosaic_nodata3_all_edit3lvcld_rle.img," and has been attributed for querying by most image processing and GIS software packages. Metadata includes pixel values associated with the excluded areas.

\section{Acknowledgments}

The author thanks the U.S. Geological Survey (USGS) Land Processes Distributed Active Archive Center (LP DAAC), the National Aeronautics and Space Administration (NASA) Earth Observing System Data and Information System (EOSDIS), and Japan's Earth Remote Sensing Data Analysis Center (ERSDAC) for providing the ASTER data used in this study. The author would also like thank the AVIRIS team at NASA Jet Propulsion Laboratory for providing the AVIRIS data. Special thanks go to K. Eric Livo of the USGS for providing the field spectral data of the parking lot at Copper Mountain ski area and reflectance-calibrated AVIRIS data of the Georgetown area that were used to calibrate the AVIRIS and ASTER data, respectively, to reflectance prior to analysis. Robert McDougal and Douglas Yager of the USGS provided helpful suggestions for the manuscript, maps, and digital data.

\section{References}

Church, S.E., San Juan, C.A., Fey, D.L., Schmidt, T.S., Klein, T.L. DeWitt, E.H., Wanty, R.B., Verplanck, P.L., Mitchell, K.A., Adams, M.G., Choate, L.M., Todorov, T.I., Rockwell, B.W., McEachron, Luke, and Anthony, M.W., 2012, Geospatial database for regional environmental assessment of central Colorado: U.S. Geological Survey Data Series 614, 76 p., http://pubs.usgs.gov/ds/614/.

Esri (Environmental Systems Research Institute), 2012, World imagery base layer: Esri, i-cubed, USDA FSA, USGS, AEX, GeoEye, AeroGRID, Getmapping, IGP, http://goto.arcgisonline.com/maps/World_Imagery.

Green, G.N., 1992, The digital geologic map of Colorado in ARC/INFO format: U.S. Geological Survey Open-File Report 92-0507, 9 p., http://pubs.usgs.gov/of/1992/ofr-920507/.

Haapala, Ilmari, 1997, Magmatic and postmagmatic processes in tin-mineralized granites: Topaz-bearing leucogranite in the Eurajoki Rapakivi granite stock, Finland: Journal of Petrology v. 38, no. 12, p. 1645-1659.

Intergraph Corporation, 2012, ERDAS IMAGINE software, http://geospatial.intergraph.com/products/ ERDASIMAGINE/ERDASIMAGINE/Downloads.aspx.

John, D.A., Rockwell, B.W., Henry, C.D., Colgan, J.P., 2010, Hydrothermal alteration of the late Eocene Caetano ashflow caldera, north-central Nevada: a field and ASTER remote sensing study: Geological Society of Nevada 2010 Symposium Volume, Reno, Nevada, May 14-22, 2010, p. 1055-1083.

Klein, T.L., 2007, The central Colorado assessmentMulti-disciplinary geoscience in support of resource management of public lands: Geological Society of America Abstracts with Programs, v. 39, no. 6, p. 627, https://gsa. confex.com/gsa/2007AM/finalprogram/abstract_131638. htm.

Neubert, J.T., Kurtz, J.P., Bove, D.J., and Sares, M.A., 2011, Natural acid rock drainage associated with hydrothermally altered terrane in Colorado: Colorado Geological Survey Bulletin 54, 114 p.

Ludington, Steve, and Plumlee, G.S., 2009, Climax-type porphyry molybdenum deposits: U.S. Geological Survey Open-File Report 2009-1215, 16 p., http://pubs.usgs.gov/ of/2009/1215/. 
Rockwell, B.W., 2002, Descriptions, spectral plots, and digital spectra of samples applied to spectral analysis of imaging spectroscopy data: Utah (East Tintic Mountains, Oquirrh Mountains, Wasatch Mountains, and Tushar Mountains), Nevada (Goldfield Hills), and New Mexico (Jemez Mountains), USA, 1999-2002: U.S. Geological Survey Open-File Report 02-407, 3 p., http://pubs.usgs. gov/of/2002/ofr-02-407/.

Rockwell, B.W., 2004, Spectral variations in rocks and soils containing ferric iron hydroxide and (or) sulfate minerals as seen by AVIRIS and laboratory spectroscopy: U.S. Geological Survey Open-File Report 2004-1431, 24 p., http://pubs. usgs.gov/of/2004/1431/.

Rockwell, B.W., 2009, Comparison of ASTER- and AVIRISderived mineral and vegetation maps of the White Horse replacement alunite deposit and surrounding area, Marysvale volcanic field, Utah: U.S. Geological Survey Scientific Investigations Report 2009-5117, 31 p., http://pubs.usgs. gov/sir/2009/5117/.

Rockwell, B.W., 2010, Mineral and vegetation maps of the Bodie Hills, Sweetwater Mountains, and Wassuk Range, California/Nevada, generated from ASTER satellite data: U.S. Geological Survey Scientific Investigations Map 3104, scale 1:62,000, 4 plates, pamphlet, 5 p., http://pubs.usgs. gov/sim/3104/.

Rockwell, B.W., 2012, Description and validation of an automated methodology for mapping mineralogy, vegetation, and hydrothermal alteration type from ASTER satellite imagery with examples from the San Juan Mountains, Colorado: U.S. Geological Survey Scientific Investigations Map 3190, 35 p. pamphlet, 5 map sheets, scale 1:100,000, http://pubs.usgs. gov/sim $/ 3190 \%$.

Rockwell, B.W., Clark, R.N., Livo, K.E., McDougal, R.R., and Kokaly, R.F., 2002a, AVIRIS data calibration information: Oquirrh and East Tintic Mountains, Utah: U.S. Geological Survey Open-File Report 02-0200, 8 p., http://pubs.usgs. gov/of/2002/ofr-02-0200/.

Rockwell, B.W., Clark, R.N., Livo, K.E., McDougal, R.R., and Kokaly, R.F., 2002b, AVIRIS data calibration information: Wasatch Mountains and Park City region, Utah: U.S. Geological Survey Open-File Report 02-0199, 8 p., http:// pubs.usgs.gov/of/2002/ofr-02-0199/.

Rockwell, B.W., Clark, R.N., Livo, K.E., McDougal, R.R., Kokaly, R.F., and Vance, J.S., 1999, Preliminary materials mapping in the Park City region for the Utah USGS-EPA Imaging Spectroscopy Project using both high- and lowaltitude AVIRIS data, in Green, R.O., ed., Summaries of the 8th Annual JPL Airborne Earth Science Workshop: NASA JPL Publication 99-17, Pasadena, California, USA, p. 365-375, http://speclab.cr.usgs.gov/earth.studies/Utah-1/ park_cityAV5.html.
Rockwell, B.W., Cunningham, C.G., Breit, G.N., and Rye, R.O., 2006, Spectroscopic mapping of the White Horse alunite deposit, Marysvale volcanic field, Utah: Evidence of a magmatic component: Economic Geology and the Bulletin of the Society of Economic Geologists, v. 101, no. 7, p. 1377-1395.

Rockwell, B.W., McDougal, R.R., and Gent, C.A., 2005, Remote sensing for environmental site screening and watershed evaluation in Utah mine lands: East Tintic Mountains, Oquirrh Mountains, and Tushar Mountains: U.S. Geological Survey Scientific Investigations Report 2004-5241, 84 p., http://pubs.usgs.gov/sir/2004/5241/, and http://speclab.cr.usgs.gov/earth.studies/Utah-1/ sir5241txto_bredit.html.

Schmidt, T.S., Clements, W.H., Wanty, R.B., Verplanck, P.L., Church, S.E., San Juan, C.A., Fey, D.L., Rockwell, B.W., Dewitt, E.H., and Klein, T.L., 2012, Geologic processes influence the effects of mining on aquatic ecosystems: Ecological Applications, v. 22, no. 3, p. 870-879.

Tweto, Ogden, 1979, Geologic map of Colorado: U.S. Geological Survey Special Geologic Map, scale 1:500,000; for explanation of units, http://geology.about.com/library/bl/ maps $/$ _statemap_COexp.htm.

Watson, D.F., 1992, Contouring-A guide to the analysis and display of spatial data: Oxford, Pergamon Press, 321 p.

Yager, D.B., Choate, LaDonna, and Stanton, M.R., 2008, Net acid production, acid neutralizing capacity, and associated mineralogical and geochemical characteristics of Animas River watershed igneous rocks near Silverton, Colorado: U.S. Geological Survey Scientific Investigations Report 2008-5063, 63 p., http://pubs.usgs.gov/sir/2008/5063/.

Publishing support provided by:

Denver Publishing Service Center

For more information concerning this publication, contact:

Center Director, USGS Central Mineral and Environmental Resources Science Center

Box 25046, Mail Stop 973

Denver, C0 80225

(303) 236-1562

Or visit the Central Mineral and Environmental Resources Science Center Web site at:

http://minerals.cr.usgs.gov/ 
